\title{
Measurement of Knowledge, attitudes and practices of parents on misuse of antibiotics in children with acute upper respiratory tract infections in Sohag district"
}

\author{
EmanA.Mohammed ${ }^{\mathrm{a}}$, Ahmed FathyHamed Ahmed ${ }^{\mathrm{b}}$,FouadM.A.Yousef ${ }^{\mathrm{c}}$, Ayat \\ khalaf Ahmed ${ }^{\text {d }}$ \\ ${ }^{\mathbf{a}}$ Professor of Public Health and Community Medicine Department -Sohag University. \\ b Assistant professor and head of Public Health and Community Medicine Department \\ Sohag University. \\ ${ }^{\mathbf{c}}$ Assistant professor of Public Health and Community MedicineDepartment - Sohag \\ University. \\ ${ }^{d}$ Demonstrator of Public Health and Community Medicine-Sohag University.
}

\begin{abstract}
Background: Upper respiratory tract infections (URTIs) are considered to be the most common reason for children's visits to outpatient clinics. The emergence and spread of resistance related to the irrational use of antibiotics is a major global public health problem. Aim of the work: This study aimed to assess parents' knowledge, attitude, and practice (KAP) regarding the use of antibiotics in URTIs in children. Methodology: A cross-sectional study wascarried out among parents $(\mathrm{N}=800)$ of children who were attending the maternal and child health center in Sohag city and the family medicine unit in Elmahamdaelbahria village in the period from $1^{\text {st }}$ July 2016 till $31^{\text {th }}$ May 2017.Results: Our results revealed that females were about $62.6 \%$, those not sharing in labor force were $55.9 \%$, and urban parents were about58.8\%. The mean age of parents was 33 years old.There is a statistically highly significant difference between mother \& father in mean scoresof knowledge, attitude, practice; they were lower in fathers. Also, there is statistically significant difference between parents with different ages in practice score. There are highly statistically significant differences between mothers who were sharing and not sharing in labor force in Attitude, Practice scores.Conclusion:Parents with loweducational level, rural residence, low income and with two children or less have lack of knowledge ,inappropriate beliefs andpractices so they are vulnerable for misusing antibiotics for their children.
\end{abstract}

\section{Introduction}

The important role of antibiotics in reducing the mortality and morbidity of diseases caused by bacteria is beyond any doubt. Despite the effectiveness of antibiotics in the treatment of numerous bacterial infections, antibiotics are being overused, particularly in children. This unjustified use of antibiotics is currently one of the major public health issues worldwide ${ }^{\mathbf{1}}$.The main problem we are facing with antibiotic therapy is that after a new antibiotic is introduced, resistance to it will, sooner or later, arise. This scenario has been seen on multiple occasions, and thus there is a continuing race between the discovery and development of new antibiotics ${ }^{2}$ In primary care settings, the common diagnosis made in children with 
respiratory symptoms is; sore throat (acute tonsillitis and acute pharyngitis), acute otitis media, acute sinusitis, common cold and acute cough/bronchitis. It is a wellknown fact that these common infections in children are mostly viral and selflimiting, thusantibiotics are most often unnecessary. Yet across the world, more than $50 \%$ of children withURTIs are treated with antibiotics, and receive on average two to three prescriptions of antibiotics per year ${ }^{3}$ Antibiotics misuse implies noncompliance with recommended therapy. The concept of noncompliance involves practices including selfprescription, failure to complete therapy, missing the doses, taking suboptimal doses, inappropriate choice of antibiotics, inappropriate combination and reuse of left over antibiotics ${ }^{4}$ The situation is difficult in countries where the sales of antibiotics are inadequately regulated and antibiotics are available without prescription ${ }^{5}$.

\section{Aim of the work:}

The aim of the current study is to assess Knowledge, attitudes, and practices of parents on use of antibiotics in children with acute upper respiratory tract infections in Sohag district and to determine the relation between parents' socio -demographic factors and their KAP.

\section{Methodology:}

A cross-sectional study wascarried out among parentsof children who were attending the maternal and child health center in Sohagcityand the family medicine unit in Elmahamdaelbahria village in the period from 1st July 2016 till 31th May 2017. Using sample size formula which is $\mathbf{N}=\mathbf{z}^{\mathbf{2}} \mathbf{p}(\mathbf{1}-\mathbf{p}) / \mathbf{d}^{\mathbf{2}}$ where:

$\mathrm{N}=$ the desired sample size.

$\mathrm{Z}=$ statistic for a level of confidence (for the level of confidence of $95 \%$, which is conventional, $\mathrm{Z}$ value is 1.96 ).
$\mathrm{P}=$ expected prevalence of the problem $(\mathrm{p}$ is considered $50 \%$ and it is expressed in the equation in decimal ,5).

$\mathrm{d}=$ precision. ( $\mathrm{d}$ is considered 0.05 to produce good precision and smaller error of estimate).

$\mathrm{N}=(1.96)^{2}\left(.5^{\times} .5\right) /(.05)^{2}=385$ but the supervisors decide to double the sample to 800 as the study performed in two places. Study tool:Data was collected through personal interview with the parents using a specially designed multi-item validated questionnaire.The questionnaire was divided into four sections; the first part included the socio-demographic characteristics of the parents, such as age, gender, educational level, family income, region of residency, and number of children. The second section assessed the parents' knowledge regarding antibiotics in general along with URTIs, stating if antibiotics have side effects, or if they think that it is easy for the pharmaceutical society to produce consistently new antibiotic drugs etc. the third section was composed of questions regarding the parents' attitude toward some ideas and behaviors about antibiotic use in URTIs,questions like which symptom and after how long would lead the parents to ask for antibiotic therapy, if they would seek for a pediatrician who is more rational use with antibiotic. The last part included questions that showed parents' practice regarding antibiotic use questions like how often they obtain antibiotic after the pediatrician has approved it by phone without having previously examined the child, or how often they insist on taking antibiotics from the pediatrician and how often the latter explains thoroughly the condition of the child and its pharmaceutical therapy. The parents' responses regarding their knowledge were recorded using a Likert scale from 1 to 5 (1 $=$ strongly agree, $2=$ agree, $3=$ uncertain, 
SOHAG MEDICAL JOURNAL Measurement of Knowledge, attitudes and practices of parents Vol. 22 No.1 Jan 2018

Ayat khalaf Ahmed

$4=$ disagree and $5=$ strongly disagree) .

The questions regarding attitude were divided into three sections. The first one asked "How often would you like your pediatrician to describe antibiotics for your child when suffer from different symptoms of URTIs ...?" with their responses ranging from $1=$ Always to $5=$ Never $(1=$ always, $2=$ most of the times, $3=$ often, 4 $=$ sometimes and $5=$ never). The second set of questions asked "How often would you give your child antibiotics without the pediatricians' advice...?" (For different six situations) with their responses ranging from $(1=$ Always to $5=$ Never $)$. The third set of questions regarding the attitude toward antibiotic use were recorded on a Likert scale ranging from 1 to $5(1=$ strongly agree, $2=$ agree, $3=$ uncertain, $4=$ disagree and $5=$ strongly disagree). There were eight questions included for the practice of using antibiotics, using the scale of $1=$ Always to $5=\operatorname{Never}(1=$

\section{Results}

Eight hundred were participated in this study, As shown in table (1) Our results revealed that The mean age of them $(33 \pm 5,9)$. About two thirds $(62.6 \%)$ of them were females. Urban parents were about 58.8\%. Mothers who weren't sharing in labor force more than who were sharing in labor force about 55.9\%. As regard household monthly income, $43.9 \%$ were had 1200-3000 L.E, 30.1\% were had more than 3000 L.E, $26.0 \%$ were had less than 1200L.E. The educational level for parents who had high school were more than other levels of education about $45.6 \%$ for fathers and $45.9 \%$ for mothers.

physician was the major parents' source of information regarding the use of antibiotics with their children suffering fromthe URTIs(44, 6\%), while mass media (television) represented(14.4\%) of mothers sources of information.

The majority of parents $380(47.5 \%)$ reported that they never want pediatrician to prescribe antibiotics for cold. However, if children had fever 244 (30.5\%) parents told that they always want an antibiotic prescription followed by sore throat that parents $230(28.8 \%)$ always want pediatricians to give the child antibiotics.(32.1\%) of parents said they always self-medicated their children with antibiotics asthepediatrician had prescribed the same antibiotic in the past for the same symptomsfor that cause. (44\%) of parents reported that they never give antibiotics for their children by themselves because of lack of money to pay a visit.

Table (2) shows that demographic factors such as residence area, parental age, gender and educational level are clearly associated with knowledge, attitudes and practices concerning judicious use of antibiotics.

There are statistically highly significant differences between mother \& father in mean scores for knowledge, attitudes and practice they were lower in fathers, $p$ values are $<0.0001$. There is 
statistically significant difference between parents with different ages in practice score, $\mathrm{P}$ values is $0 . \cdot T r$, There are statistically significant differences between urban and rural parents in mean scores of Knowledge, Attitude, Practice scores they were lower in rural parents than in urban parents $\mathrm{p}$ values are $0.003,0.003,0.041$ respectively.

Table (3) is showing factors affecting parents knowledge, attitude and practice scores regarding antibiotic use for their children with URTIs. There were six independent factors; occupation the father, occupation of mother, education of mother and number of children are with positive relation to knowledge score. Gender and age are with negative relation with knowledge score, as females had

better total mean score. Also, there were four independent factors; education of mother and number of children are with positive relation with attitude score. Gender and age are with negative relation with attitude score. There were four independent factors affectedpractice score as there was negative relation between mean score and each of age and gender. and positive relation between score and each of education of mother, number of children.

\section{Discussion}

The use of antibiotics in clinical practice in the second half of the twentieth century constituted major achievement in medical history, leading to the prevention, treatment and control of several fearful infectious diseases of the past. However, the emergence and spread of antibiotic resistant or pathogens is a public health threatwith the unavailability of novel antibiotics ${ }^{6}$. In most cases of URTIs, antibiotics are not required as most URTIs are self-limiting and caused by viruses with very minimal risk of complications and their management typically involvesselfcare and symptomatic treatment ${ }^{7}$.It is worth noticing that, parents believe that scientists continuously discover new antimicrobials and therefore do not realize the problems faced by the scientific society with shortage of newantimicrobials ${ }^{\mathbf{8}}$.Thus, the parental knowledge, attitude and practice on antibiotic use in childhood common URTIs is a matter of great interest and importance, and this study is trying to address these issues in particular.In our study, physician was the main Parents' source of information regarding the use of antibiotics with their children which is similar to what had been reported by Saudi parents who reported that information regarding antibiotic use and resistance came from their physicians ${ }^{9}$.This is similar to cross sectional study which was performed in primary health care centers in Nablus city from 1 June to 31 October 2012 which had shown that almost two thirds of parents indicated their pediatricians as the main source of information about use or misuse ofantibiotics ${ }^{10}$. When parents were given possible treatment options for management of URTIs, more than half of participants chose antibiotic therapy, Similarly cross sectional KAP study involving 385 parents in Palestine showed that more than two thirds of participants expect antibiotic therapy from pediatrician for treatment of URTIs ${ }^{10}$.We found that about $44 \%$ of parents had self-medicated their children with antibiotics. This finding is much higher than the results of previous studies, which found, for example, that $36 \%$ of parents in an urban area of China ${ }^{11 .} 12 \%$ of parents in suburban areas of Greece ${ }^{\mathbf{1 2}}$ and $23 \%$ of parents in urban areas of Greece ${ }^{\mathbf{1 3}}$ The present study found that more than two thirds of parents agreed to being informed about judicious antibiotic use so 
that they can avoid from using antibiotics for the wrong indication, this is similar to finding in cross sectional study was conducted in Malaysia ${ }^{\mathbf{1 4}}$. It was found that there was statistically significant difference in means of Knowledge, Attitude, Practice scores about antibiotics use in different educational levels as it increased with increasing educational level. This is in harmony with Chan and Tang who had shown that attitude toward antibiotic use was found to have significant association with educational levels as parents with higher educational levels may understand more about the proper indication for antibiotics and they may be aware of the undesirable effects of over prescription of antibiotics ${ }^{15}$.

\section{Conclusion}

Upper respiratory tract infections in children are common conditions for families, healthcare providers, and health systems. Parents use antibiotics frequently for URTIs, despite the fact that most are self-limiting and need only supportive treatment. Overuse of antibiotics is associated with development of antimicrobial resistance, and adverse effects.demographic factors such as residence area, parental age, gender and educationallevel are associated with knowledge, attitudes and practices concerning judicious antibiotic use with children.

\section{Recommendations:}

Improvement in the appropriate use of antibiotics will require multi-sectoral cooperation and longtermefforts. Health education and interventions forparentscould be conducted through physicians, massmedia, and community approaches. The contents of health education should include the basic Concepts of antibiotics, the appropriate indications and administration and the potentialhazards of medicating children with antibiotics. Physicians play a key role in health education, as they were the main source of information on antibiotics for parents. 
SOHAG MEDICAL JOURNAL Measurement of Knowledge, attitudes and practices of parents Vol. 22 No.1 Jan 2018 Ayat khalaf Ahmed

Table(1): Socio-demograghic characteristics of the studied parents in Sohag district 2016

\begin{tabular}{|c|c|c|}
\hline Socio-demographic data & No $(800)$ & $\%$ \\
\hline $\begin{array}{l}\text { Person completing the questionnaire } \\
\text { Mother } \\
\text { Father }\end{array}$ & $\begin{array}{l}0.1 \\
\text { r99 }\end{array}$ & $\begin{array}{l}T Y .4 \\
r .4\end{array}$ \\
\hline $\begin{array}{l}\text { Age of participant:- } \\
r-r_{0} \\
26-30 \\
31-35 \\
36-40 \\
40-45 \\
\text { Mean age }(33 \pm 5,9)\end{array}$ & $\begin{array}{l}1.1 \\
r \leqslant v \\
114 \\
r i r \\
1 r r\end{array}$ & $\begin{array}{l}15.9 \\
r .99 \\
18.0 \\
19.9 \\
10.4\end{array}$ \\
\hline $\begin{array}{l}\text { Mother educational level: } \\
\text { Illiterate } \\
\text { Primary school } \\
\text { Secondry school } \\
\text { High school } \\
\text { University\&post graduate }\end{array}$ & $\begin{array}{l}19 \\
v V \\
1.9 \\
\text { riv } \\
\text { rYs }\end{array}$ & $\begin{array}{l}r .9 \\
9.9 \\
1 r .9 \\
40.9 \\
r 1.0\end{array}$ \\
\hline $\begin{array}{l}\text { Father educational level: } \\
\text { Illiterate } \\
\text { Primary school } \\
\text { Preparatory school } \\
\text { High school } \\
\text { University\&post graduate }\end{array}$ & $\begin{array}{l}r \\
i n \\
11 r \\
r i o \\
224\end{array}$ & $\begin{array}{l}r .1 \\
\Lambda .0 \\
1 . .1 \\
\varepsilon 0.9 \\
r \Lambda_{.} .\end{array}$ \\
\hline $\begin{array}{l}\text { Father occupation: } \\
\text { Laborer } \\
\text { Official } \\
\text { Technician } \\
\text { private business } \\
\text { Professional }\end{array}$ & $\begin{array}{l}r \cdot v \\
i n A \\
i v a \\
i r \mid \\
1.0\end{array}$ & $\begin{array}{l}r o .9 \\
r y .0 \\
r Y .4 \\
10.1 \\
1 r .1\end{array}$ \\
\hline $\begin{array}{l}\text { Mother occupation: } \\
\text { Sharing in labor force } \\
\text { Not sharing in labor force }\end{array}$ & $\begin{array}{l}r \Delta r \\
\leq \leqslant V\end{array}$ & $\begin{array}{l}\varepsilon \leqslant .1 \\
00.9\end{array}$ \\
\hline $\begin{array}{l}\text { Monthly income: } \\
<1200 \\
1200-3000 \\
>3000\end{array}$ & $\begin{array}{l}r \cdot 1 \\
r \otimes 1 \\
r \leqslant 1\end{array}$ & $\begin{array}{l}r q .9 \\
\varepsilon r .9 \\
30.1\end{array}$ \\
\hline $\begin{array}{l}\text { Residence: } \\
\text { Urban } \\
\text { Rural }\end{array}$ & $\begin{array}{l}\varepsilon v . \\
r r .\end{array}$ & $\begin{array}{l}0 \Lambda_{.} \wedge \\
\Sigma \Lambda_{.}\end{array}$ \\
\hline $\begin{array}{l}\text { Number of children: } \\
1 \\
r \\
r \\
\leq 5 \\
\end{array}$ & $\begin{array}{l}\text { rVq } \\
r r q \\
\text { lor } \\
94 \\
\varepsilon r\end{array}$ & $\begin{array}{l}r<.9 \\
r 1.9 \\
19.1 \\
14.9 \\
0.4\end{array}$ \\
\hline
\end{tabular}


SOHAG MEDICAL JOURNAL Measurement of Knowledge, attitudes and practices of parents Vol. 22 No.1 Jan 2018 Ayat khalaf Ahmed

\section{Table(2):Comparison of knowledge, attitude and practice scores by socio-demographic charactristics.}

\begin{tabular}{|c|c|c|c|c|}
\hline Variable & No $(800)$ & knowledge score mean \pm SD & attitude score mean \pm SD & practice score mean \pm SD \\
\hline $\begin{array}{l}\text { Gender } \\
\text { Mother } \\
\text { Father } \\
\text { P value }\end{array}$ & $\begin{array}{l}0.1 \\
\text { raq }\end{array}$ & $\begin{array}{c}r r . V \pm 5.8 \\
17.8 \pm 4.8 \\
<0.0001\end{array}$ & $\begin{array}{c}\vee \vee . q \pm \mathbf{1 8 . 5} \\
\checkmark \cdot \vee_{ \pm} \mathbf{1 3 . 7} \\
<\mathbf{0 . 0 0 0 1}\end{array}$ & $\begin{array}{l}r \vee . r \pm 7.3 \\
r \cdot . \pm 5.9 \\
<\mathbf{0 . 0 0 0 1}\end{array}$ \\
\hline $\begin{array}{l}\text { Age of participant:- } \\
r-r_{0} \\
26-30 \\
31-35 \\
36-40 \\
40-45 \\
\text { P value }\end{array}$ & $\begin{array}{l}1.1 \\
r \leq v \\
114 \\
r 1 \% \\
1 r r\end{array}$ & $\begin{array}{c}r . r \pm 7.5 \\
r . \ominus \pm 6.5 \\
r 1 . \ominus \pm 3.9 \\
21.4 \pm 5.8 \\
21.8 \pm 6.7 \\
. \wedge \uparrow \diamond\end{array}$ & $\begin{array}{c}\vee 9.1 \pm 23.0 \\
\vee 1 . \checkmark \pm 19.1 \\
71.8 \pm 11.8 \\
v \cdot . v \pm 18.8 \\
v r .9 \pm 19.5 \\
.329\end{array}$ & $\begin{array}{c}r Y . q \pm 8.6 \\
r \varepsilon .1 \pm 7.7 \\
r 0 . r \pm 5.1 \\
r \varepsilon . \varepsilon \pm 7.6 \\
r 0.9 \pm 8.4 \\
.032\end{array}$ \\
\hline $\begin{array}{l}\text { Mother educational level: } \\
\text { Illiterate } \\
\text { Primary school } \\
\text { Preparatoryschool } \\
\text { High school } \\
\text { University\&post graduate } \\
\text { P value }\end{array}$ & $\begin{array}{l}19 \\
V V \\
1.9 \\
\text { miv } \\
r Y A\end{array}$ & $\begin{array}{l}1\{. \cdot \pm 3.1 \\
\mid r .9 \pm 3.0 \\
16.1 \pm 3.9 \\
20.8 \pm 3.9 \\
28.3 \pm 3.4 \\
<0.0001\end{array}$ & $\begin{array}{l}\varepsilon \vee . \cdot \pm 5.2 \\
\varepsilon q . \vee \pm 7.7 \\
53.1 \pm 9.2 \\
69.3 \pm 12.1 \\
q r . \curlyvee \pm 9.6 \\
<0.0001\end{array}$ & $\begin{array}{l}10 . r \pm \mathbf{2 . 0} \\
10.9 \pm \mathbf{2 . 6} \\
1 V . r \pm \mathbf{4 . 1} \\
r r . r \pm 5.5 \\
r r . \cdot \pm \mathbf{3 . 9} \\
<\mathbf{0 . 0 0 0 1}\end{array}$ \\
\hline $\begin{array}{l}\text { Father educational level: } \\
\text { Illiterate } \\
\text { Primary school } \\
\text { Preparatory school } \\
\text { High school } \\
\text { University\&post graduate } \\
\text { P value }\end{array}$ & $\begin{array}{l}m \\
41 \\
114 \\
r y o \\
224\end{array}$ & $\begin{array}{l}1 r .7 \pm 3.1 \\
1 \leq .0 \pm 3.2 \\
17.1 \pm 4.8 \\
20.7 \pm 4.0 \\
28.3 \pm 3.7 \\
<0.0001\end{array}$ & $\begin{array}{c}\varepsilon \curlyvee .9 \pm 5.1 \\
\odot \cdot . \diamond \pm 7.9 \\
56.3 \pm 12.4 \\
68.8 \pm 12.4 \\
9 r .1 \pm 10.0 \\
<0.0001\end{array}$ & $\begin{array}{l}10.9 \pm 2.1 \\
17.11 \pm 2.8 \\
1 \wedge . r \pm 5.1 \\
r r .0 \pm 5.6 \\
r r . \cdot . \pm 3.9 \\
<0.0001\end{array}$ \\
\hline $\begin{array}{l}\text { Father occupation } \\
\text { Laborer } \\
\text { Official } \\
\text { Technician } \\
\text { private business } \\
\text { Professional } \\
\text { P value } \\
\end{array}$ & $\begin{array}{l}r \cdot v \\
i n \\
i v a \\
i r 1 \\
1.0\end{array}$ & $\begin{array}{c}21.0 \pm 4.4 \\
r .0 \pm 6.3 \\
20.6 \pm 7.2 \\
21.2 \pm 6.7 \\
r .0 \pm 5.8 \\
0.037\end{array}$ & $\begin{array}{l}68.3 \pm 14.2 \\
\vee\urcorner . r \pm 19.3 \\
69.7 \pm 21.1 \\
\vee \cdot . \cdot \pm 19.8 \\
\vee r . v \pm 18.7 \\
<0.0001\end{array}$ & $\begin{array}{l}r r . r \pm 5.9 \\
r Y . r \pm 7.0 \\
r r .0 \pm 8.5 \\
r \varepsilon . r \pm 8.1 \\
r 0.1 \pm 7.9 \\
<0.0001\end{array}$ \\
\hline $\begin{array}{l}\text { Mother occupation: } \\
\text { Sharing in labor force } \\
\text { Not sharing in labor force } \\
\text { P value }\end{array}$ & $\begin{array}{l}\text { ror } \\
\varepsilon \leqslant V\end{array}$ & $\begin{array}{l}r . \wedge \pm 7.1 \\
21.3 \pm 5.2 \\
. \uparrow r\end{array}$ & $\begin{array}{c}V r . \checkmark \pm 20.6 \\
\curlyvee 9 . \wedge \pm 17.1 \\
. \cdots 9\end{array}$ & $\begin{array}{c}r 0 . r \pm 8.2 \\
r r . \wedge \pm 7.0 \\
. \cdots 9\end{array}$ \\
\hline $\begin{array}{l}\text { Monthly income: } \\
<1200 \\
1200-3000 \\
>3000 \\
\text { P value }\end{array}$ & $\begin{array}{l}r+1 \\
r 01 \\
r \leq 1\end{array}$ & $\begin{array}{c}20.5 \pm 6.4 \\
22.0 \pm 5.0 \\
21.6 \pm 7.2 \\
.007\end{array}$ & $\begin{array}{l}Y \vee . r \pm 19.0 \\
73.4 \pm 15.8 \\
V Y . Y \pm 21.9 \\
<0.0001\end{array}$ & $\begin{array}{l}r Y . T \pm 8.0 \\
Y Y . \diamond \pm 6.3 \\
Y V . V \pm 8.7 \\
<0.0001\end{array}$ \\
\hline $\begin{array}{l}\text { Residence: } \\
\text { Urban } \\
\text { Rural } \\
\text { P value } \\
\end{array}$ & $\begin{array}{l}\text { \&v. } \\
\text { r. }\end{array}$ & $\begin{array}{c}22.2 \pm 6.4 \\
ץ . \cdot \pm 5.9 \\
0.003\end{array}$ & $\begin{array}{c}V \Psi .9 \pm 18.7 \\
79.9 \pm 18.7 \\
0.003\end{array}$ & $\begin{array}{c}r \cdot Y^{Y} \pm 7.6 \\
r \varepsilon . \cdot \pm 7.6 \\
0.041\end{array}$ \\
\hline $\begin{array}{l}\text { Number of children: } \\
1 \\
r \\
r \\
\leq 5 \\
\text { v value }\end{array}$ & $\begin{array}{l}\text { iva } \\
\text { req } \\
\text { lor } \\
94 \\
\varepsilon r\end{array}$ & $\begin{array}{l}17.0 \pm 4.0 \\
\vdash \cdot v \pm 5.0 \\
25.6 \pm 4.0 \\
27.9 \pm 3.6 \\
29.3 \pm 3.7 \\
<0.0001\end{array}$ & $\begin{array}{l}\bullet \leqslant .0 \pm 10.3 \\
v \cdot . \cdot \pm 14.5 \\
85.9 \pm 11.1 \\
91.0 \pm 11.0 \\
q r . q \pm 9.8 \\
<0.0001\end{array}$ & $\begin{array}{l}r \vee . r \pm 3.8 \\
r \varepsilon . \cdot \pm 5.8 \\
r \cdot . T \pm 4.0 \\
r r . \varepsilon \pm 4.2 \\
r \varepsilon . r \pm 3.3 \\
<0.0001\end{array}$ \\
\hline
\end{tabular}


SOHAG MEDICAL JOURNAL Measurement of Knowledge, attitudes and practices of parents Vol. 22 No.1 Jan 2018

Ayat khalaf Ahmed

Table (3): Multiple linear regression model between different factors

\begin{tabular}{|c|c|c|}
\hline \multicolumn{3}{|c|}{ Knowledge Score } \\
\hline Independent item & Regression coefficient $(95 \%$ CI) & $P$ value \\
\hline Gender & $-2.65(-3.16:-2.128)$ & $<.0001$ \\
\hline Age & $-.45(-.64:-.25)$ & $<.0001$ \\
\hline Occupation of father & $.21(.02: .41)$ & .034 \\
\hline Occupation of mother & $.64(.16: 1.12)$ & .009 \\
\hline Education of mother & 2.53 (1.76: 3.32) & $<.0001$ \\
\hline Number of children & $1.96(1.71: 2.22)$ & $<.0001$ \\
\hline \multicolumn{3}{|c|}{ Attitude Score } \\
\hline Independent item & Regression coefficient $(95 \%$ CI) & P value \\
\hline Gender & $-6.33(-7.81:-4.86)$ & $<.0001$ \\
\hline Age & $-1.20(-1.75:-.66)$ & $<.0001$ \\
\hline Education of mother & 6.76 (4.54: 8.97) & $<.0001$ \\
\hline Number of children & $6.76(6.03: 7.49)$ & $<.0001$ \\
\hline \multicolumn{3}{|c|}{ Practice Score } \\
\hline Independent item & Regression coefficient $(95 \%$ CI) & P value \\
\hline Gender & $-2.73(-3.33:-2.12)$ & $<.0001$ \\
\hline Age & $-.28(-.50:-.05)$ & .03 \\
\hline Education of mother & 2.81 (1.91: 3.72) & $<.0001$ \\
\hline Number of children & 3.13 (2.83: 3.42) & $<.0001$ \\
\hline
\end{tabular}

\section{References}

1- Kisuule F, Wright S, Barreto J, Zenilman J. Improving antibiotic utilization among hospitalists: a pilot academic detailing project with a public health approach. Journal of hospital medicine. 2008 Jan 1; 3 (1):64-70

2- Kotwani A, Wattal C, Katewa S, Joshi PC, Holloway K. Factors influencing primary care physicians to prescribe antibiotics in Delhi India. Family practice. 2010 Jul 26; 27 (6):684-90.

3- Finkelstein JA, Metlay JP, Davis RL, Rifas-Shiman SL, Dowell SF, Platt R. Antimicrobial use in defined populations of infants and young children.Archives of pediatrics \& adolescent medicine. 2000 Apr 1; 154 (4):395-400.
4-Kardas P, Devine S, Golembesky A, Roberts C. A systematic review and meta-analysis of misuse of antibiotic therapies in the community. International journal of antimicrobial agents. 2005 Aug 31; 26 (2):106-13.

5-Cully M. The politics of antibiotics: policy-makers and medical experts need to think globally if we are to prevent an antibiotic' tragedy of the commons'. Nature. 2014 May 1; 509 (7498 SI):5168.

6-Albrich WC, Monnet DL, Harbarth S. Antibiotic selection pressure and resistance in Streptococcus pneumoniae and Streptococcus pyogenes.Emerging 
SOHAG MEDICAL JOURNAL Measurement of Knowledge, attitudes and practices of parents Vol. 22 No.1 Jan 2018 Ayat khalaf Ahmed

infectious diseases. 2004 Mar; 10 (3):514.

7- Sarahroodi S, Arzi A, Sawalha AF, Ashtarinezhad A. Antibiotics selfmedication among southern iranian university students. IJP-International Journal of Pharmacology. 2010;6 (1):4852.

8- Van De Sande-Bruinsma N, Grundmann H, Verloo D, Tiemersma E, Monen J, Goossens H, Ferech M. European Antimicrobial Resistance Surveillance System. Antimicrobial drug use and resistance in Europe.Emerging infectious diseases. 2008 Nov; 14(11):1722.

9-Al-Dossari K. Parental knowledge, attitude and practice on antibiotic use for upper respiratory tract infections in children. Majmaah Journal of Health Sciences. 2013 Apr; 1 (1):33-45

10-Saed HZ, Taha AA, Araj KF, Abahri IA, Sawalha AF, Sweileh WM, Awang R, Al-Jabi SW. Parental knowledge, attitudes and practices regarding antibiotic use for

acute upper respiratory tract infections in children: a cross-sectional study in Palestine. BMC pediatrics. 2015 Nov 11; 15 (1):176.
11-Bi P, Tong S, Parton KA.Family selfmedication and antibiotics abuse for children and juveniles in a Chinese city.Social science \& medicine. 2000 May 16; 50 (10):1445-50.

12-Edwards DJ, Richman PB, Bradley $\mathbf{K}$,Parental use and misuse of antibiotics: are there differences in urban vs. suburban settings? Academic emergency medicine. 2002 Jan 1; 9 (1):22-6.

13-Mitsi G, Jelastopulu E, Basiaris H, Skoutelis A, Gogos C. Patterns of antibiotic use among adults and parents in the community: a questionnaire-based survey in a Greek urban population. International journal of antimicrobial agents. 2005 May 31; 25(5):439-43.

14-Islahudin F, TameziAM, Shah NM. Knowledge, attitudes and practices about antibiotic use among the general public in Malaysia. Southeast Asian Journal of Tropical Medicine and Public Health. 2014 Nov 1; 45(6):1474.

15- Chan GC, Tang SF. Parental knowledge, attitudes and antibiotic use for acute upper respiratory tract infection in children attending a primary healthcare clinic inMalaysia.Malaysian Family Physician. 2012 Mar 31; 2 (1):5. 